\title{
Principals' Attitudes towards ICT and Their Perceptions about the Factors That Facilitate or Inhibit ICT Integration in Primary Schools of Cyprus
}

\author{
Photos Papaioannou \\ Ministry of Education and \\ Culture, Nicosia, Cyprus
}

fotospap@hotmail.com

\author{
Kyriacos Charalambous \\ School of Education, Frederick \\ University, Nicosia, Cyprus
}

kyriacoscharalambous@gmail.com

\section{Executive Summary}

This study explores the Cyprus primary school principals' attitudes towards Information and Communication Technologies (ICT) as well as their perceptions about the factors that facilitate or inhibit ICT integration in primary schools in Cyprus.

A sequential mixed method approach was used to answer the research questions that guided this study. First, a survey was conducted among principals. Using a stratified random sampling 250 primary school principals from all over Cyprus (total population was 336) participated in this study. Data were collected through questionnaires, which were mailed to the principals. One hundred and thirty one questionnaires were received completed (response rate 52.4\%). Then, a qualitative approach was followed. Eight principals were chosen to be interviewed based on specific criteria. The mixed method approach was chosen in order to safeguard the purpose of triangulation, complementarity, and expansion. Quantitative data were analyzed using the statistical package SPSS and descriptive and inferential statistics were used to answer the research questions. The method of qualitative content analysis was used for the analysis of the qualitative data.

Cyprus primary school principals, generally, hold positive attitudes towards ICT. However, a number of statistically significant differences were observed across gender, years of service, academic qualifications, access to a computer and the internet at home, in-service training on ICT for teaching and learning purposes, existence of a computer in the principal's office, computer experience, and the principals' attitudes towards ICT. In addition, even though principals value the importance of ICT in the teaching and learning process as well as for the fulfilment of their managerial and administrative purposes, they still need more tailor-made in-service training and incentives in order to transfer their theoretical enthusiasm into practice.

Material published as part of this publication, either on-line or in print, is copyrighted by the Informing Science Institute. Permission to make digital or paper copy of part or all of these works for personal or classroom use is granted without fee provided that the copies are not made or distributed for profit or commercial advantage AND that copies 1) bear this notice in full and 2) give the full citation on the first page. It is permissible to abstract these works so long as credit is given. To copy in all other cases or to republish or to post on a server or to redistribute to lists requires specific permission and payment of a fee. Contact Publisher@InformingScience.org to request redistribution permission.
Moreover, principals are aware of a number of factors that can facilitate or inhibit ICT integration. These factors can be divided in two main categories: internal factors (inspiring and competent leadership, school-based in-service training on ICT, capable ICT coordinator, provision of incentives to the ICT coordinator, involvement of primary stakeholders in the integration process, collaboration with the district ICT advi- 
sory teacher, teachers' competence and knowledge on ICT, acceptance of the innovation from the teachers) and external factors (centre-based in-service training on ICT, pupils' background knowledge on ICT, technical support-maintenance of ICT, time available for principals to prepare the ICT integration, number of computers per class, support of the innovation from the Ministry of Education and Culture).

Keywords: primary education, principals' attitudes, ICT integration, Cyprus, factors facilitate ICT integration

\section{Introduction}

In the modern era, Information and Communication Technologies (ICT) play a crucial role in the way that society functions. The future of the economy and the citizens' prosperity are strongly correlated with ICT integration in every aspect of life (J. Anderson, 2010; Sciadas, 2004). The European Union (EU), recognizing the necessity to keep up with the rapid technological changes and to enhance lifelong learning among its citizens, promoted the strategic framework "i2010-A European Information Society for growth and employment" in order to improve the overall quality of life and to meet the challenges of globalization, ageing, and the ICT revolution (Dion, 2005, p. 295). The success of the i2010 strategic framework could never be a reality without the integration of ICT in education, since education would prepare future citizens to learn and use ICT in daily life and work. Therefore, EU countries invested huge amounts of money to integrate ICT and modernize their educational and training systems in order to meet the demands of the knowledge-based economy and society. The emphasis on ICT integration in education is growing year by year and much more money is about to be invested in the years to come (Eurydice, 2011).

ICT were introduced in the public primary schools of Cyprus at the beginning of the previous decade not as a discrete subject, but as a learning tool that should be integrated in all subjects of the curriculum. Many years after the introduction of ICT, with many millions spent on teachers' training and on equipping schools with hardware, software, and relevant infrastructure (Doratis, 2007), ICT are still not integrated in all subjects of the curriculum. A survey from Empirica (2006) indicates that only $7.9 \%$ of the primary school teachers use computers in class in more than $50 \%$ of their lessons, whereas more than $35 \%$ of primary school teachers use computers in class in less than $10 \%$ of their lessons. Moreover, a study that was conducted among primary school teachers in 2004 revealed that $53 \%$ of the teachers hold negative attitudes towards computer technology integration in their classroom practices (Eteokleous, 2008). It can therefore be inferred that ICT integration in primary school in Cyprus cannot be considered as successful yet.

Policy makers, in the centralized educational system of Cyprus, focused their efforts mainly on equipping the schools with more technological resources and providing in service training sessions to all the teachers. On the other hand, they paid little attention to the principals' role in achieving the innovation. But, according to R. E. Anderson and Dexter (2005), a "school's technology efforts are seriously threatened unless key administrators become active technology leaders in a school" (p. 74). Moreover, Pelgrum (1993) examined the impact of the attitudes of school principals and teachers and concluded that "there is a clear association between the attitudes of school principals and the emphasis on computer integrated learning within the school" (p. 209).

This study aims to present Cyprus primary school principals' attitudes towards ICT, as well as their perceptions about the factors that facilitate or inhibit ICT integration in primary schools in Cyprus. The paper first presents the educational context of the study (the educational system of Cyprus, the role of the public primary school principal, and the history of ICT implementation in primary schools of Cyprus) followed by the literature on the teachers' and principals' attitudes towards ICT and how these attitudes can affect the ICT integration efforts. Then the methodology of the study is described. Lastly, the findings of the study are presented and discussed. 
The current study is the only one carried out in Cyprus regarding principals' attitudes towards ICT, as well as their perceptions about the factors that facilitate or inhibit ICT integration in primary schools. Therefore, its results might reveal whether primary school principals are ready to lead this innovation or whether policy makers should focus their efforts on amplifying principals' capacity to lead effectively ICT integration in schools.

\section{The Educational Context of the Study}

\section{The Cyprus Educational System (CES)}

The administration of the public CES of Cyprus is very bureaucratic and inflexible. In addition, the governing and monitoring of CES are highly centralized. The overall power and control is concentrated in the hands of the Ministry of Education and Culture (MOEC), which is responsible for the administration of education and the enforcements of educational laws, as well as the preparation of educational legislation. Along with the Office of the Attorney General, they prepare the educational bills, which are tabled for debate and approval by the House of Representatives. Moreover, MOEC determines the syllabi, the curricula, and the timetables and provides the textbooks and the educational material needed for the functioning of the schools.

\section{The Role of Primary School Principals in the Educational System of Cyprus}

The centralized structure of CES deteriorates the role of principals in primary schools. According to official regulations of MOEC about the functioning of public primary schools, the main responsibilities of school principals are to run their school effectively, promote the implementation of the national curriculum, undertake instructional duties, and keep school records, school register and attendance records, etc. On the other hand, they do not have a say in which school they would like to be appointed. Moreover, they do not have the authority to recruit their teaching personnel since this is a responsibility of the Educational Service Committee, and, of course, they have no influence over the salary of their staff. Additionally, according to the educational law, principals - like teachers - are not allowed to stay in the same school for more than six consecutive years. It should also be mentioned that the principals' involvement in curriculum development is very limited (Ministry of Education and Culture [MOEC], 2008).

\section{Brief History of ICT Implementation in the Primary Schools in Cyprus}

MOEC followed a centralized approach to introduce ICT in primary schools in the early 1990s (Charalambous \& Karagiorgi, 2002). Although the innovation was top-down, "the strategy for ICT integration involved a combination of centralized initiative and largely decentralized implementation policy" (Karagiorgi \& Charalambous, 2004, p. 22). According to MOEC, ICT should not be used as a discrete subject but as a dynamic means "in the teaching and learning process aiming at a more effective implementation of the school curriculum and developing of skills such as problem solving, decision making, communication and information handling." (Ministry of Education and Culture, 2007a, p. 274). Today, twenty years after the initial efforts for ICT integration, all classrooms have at least one computer (the immediate goal of MOEC is to increase computers per classroom up to three), a scanner, and a printer. Additionally, all schools have access to the internet through ISDN or ADSL lines. It should also be mentioned that in-service training programmes for the use of ICT have been developed by the Pedagogical Institute of Cyprus. MOEC in its latest "Strategic Planning for Education" emphasises ICT integration by stating that CES should "integrate and use ICT in its daily procedures as far it concerns the manage- 
ment of the school system and the school units, as well as the teaching and learning process" (Ministry of Education and Culture, 2007b, p. 49).

\section{Literature Review}

The introduction of ICT in schools in the 1990s led to a general belief that computer technology would transform the existing educational system, raise the effectiveness and efficiency of the teaching and learning methods, and increase student achievement. Many research studies have been carried out emphasizing the benefits of using ICT for teaching and learning purposes (Scrimshaw, 2004). Some findings stressed that ICT can motivate pupils, increase their selfconfidence and self-esteem, stimulate their interest, increase their attainment, allow greater interactivity and individualization, enhance the pupils' critical thinking, increase their creativity, etc. (Newhouse, 2002). Additionally, the ICT Impact Report (Balanskat, Blamire, \& Kefala, 2006) and BECTA (2004a) also state that ICT can increase teachers' enthusiasm and efficiency, promote their co-operation and planning with ICT, reduce their workload, help them alter their traditional pedagogical beliefs, implement new pupil-centred teaching strategies, and enhance stronger relationships between teachers and pupils, amongst others.

Once again, after the easy access to a wealth of knowledge about the benefits of ICT for teaching and learning purposes, the teacher becomes the centre of the reform efforts. Staff development programs were initiated, whereas enormous sums of money were spent equipping the schools with the necessary technology infrastructure. However such a significant drive for innovation, which would inevitably reform the way that schools work, could never be achieved without the contribution of the school leader who must lead the school's efforts and act as a change agent (Murphy \& Shipman, 1999). Of course, this can only be done if the principal believes in the innovation and has a positive attitude towards it. Actually, the attitude of the principal will determine if this innovation is going to succeed or fail (Pelgrum, 1993).

Fishbein and Ajzen (1975) described attitude as "learned pre-disposition to respond in a consistently favourable and unfavourable manner with respect to a given object" (p. 6). During the last two decades, with the wide expansion of technology in schools, a considerable number of research studies have been conducted about the attitudes of educators (teachers and principals) towards ICT integration (Jimoyiannis \& Komis, 2007; Wen \& Shih, 2008). The results indicate that a respectable number of educators hold a negative attitude towards ICT integration, exhibiting negative reactions to computers ranging from "mild discomfort to extreme avoidance" (Todman, 2000, p. 27). Computer anxiety is a "real phenomenon" (Moldafsky, \& Kwon, 1994, p. 301) which is evident "at close to one-third of the industrialized population of the world" (Korukonda \& Finn, 2003, p. 80).

Many attitude scales have been constructed to assess the attitudes of students, teachers, and principals towards ICT (Christensen \& Knezek, 1998; Korukonda \& Finn, 2003; Rosen \& Weil, 1995a). The scales consisted of various subscales, which can be summarized in four general categories: (a) Computer Anxiety/Avoidance/Aversion, (b) Self-efficacy/ Confidence, (c) Enthusiasm/Liking/Enjoyment, and (d) Usefulness/Negative Consequences in Personal and Social Life. The most prevalent independent variables that have been used to assess the teachers and principals attitudes towards ICT can be categorized in two groups: demographics (age and gender) and computer experience (training, years of using computer, ownership of computer, access to a computer, intensity of computer use).

The school leaders' attitudes towards ICT should be of primary concern. Principals' positive attitudes, enthusiasm, and commitment towards ICT integration can play a significant role in overcoming the various impediments that occur during the integration process. According to Pelgrum (1993), "schools, whose principals have positive expectations regarding the educational impact of 
computers, tend to emphasize computer integrated learning more than schools with principals who are less positive" (p. 209). In addition, Walsh (2002) stresses that ICT integration could be achieved in schools only if school leaders are totally committed over a period of time. Initially principals who believe in ICT develop strategies to sustain technology in their school and tend to support the efforts of their staff to integrate technology in their teaching by helping them understand "the potential of the technologies available and of how they can become integrated into the day-to-day life of the school" (BECTA, 2007, p.20).

It is clear that school leaders with positive attitudes towards ICT integration can facilitate integration to a great extent. Additionally, several other factors have been identified as the "enablers" of ICT integration. For example a leadership role should include "a strong professional vision for meaningful technology integration in teaching and learning" (Mrazek, Hollingsworth, \& Street, 2005, p.5). Other ICT enablers and barriers to ICT integration, identified by BECTA (2004b; 2007) are outlined in Table 1.

\section{Table 1: Enablers and barriers to ICT integration}

\begin{tabular}{|l|l|}
\hline \multicolumn{1}{|c|}{ Enablers to ICT integration (BECTA 2007) } & \multicolumn{1}{|c|}{ Barriers to ICT integration (BECTA 2004b) } \\
\hline $\begin{array}{l}\text { Participation of teachers in the decision making } \\
\text { process of the school }\end{array}$ & $\begin{array}{l}\text { Lack of teacher's confidence and computer anx- } \\
\text { iety }\end{array}$ \\
$\begin{array}{l}\text { Collaboration and knowledge-sharing among teach- } \\
\text { Lack of teacher's competence, the lack of ac- } \\
\text { Cultivation of a culture of innovation and experi- } \\
\text { mentation in the school }\end{array}$ & $\begin{array}{l}\text { Lack of time (for preparation of computer based } \\
\text { lesson) } \\
\text { Continuous technical support }\end{array}$ \\
$\begin{array}{l}\text { Existence of a specific technology plan about ICT } \\
\text { integration }\end{array}$ & Teachers' resistance to change \\
$\begin{array}{l}\text { The administrative computer competence } \\
\text { Continuous in-service training on ICT }\end{array}$ & \\
$\begin{array}{l}\text { Provision of time to the staff "to meet and establish } \\
\text { trust needed to be built into the process, with roles } \\
\text { and responsibilities clearly identified" (p.7) }\end{array}$ & \\
$\begin{array}{l}\text { Existence of the appropriate infrastructure and re- } \\
\text { sources }\end{array}$ & \\
$\begin{array}{l}\text { Existence of capable ICT coordinators within the } \\
\text { schools }\end{array}$ & \\
\hline
\end{tabular}

The last item in the barriers list, i.e., teachers' resistance to change (BECTA, 2004b), is probably the most important factor towards ICT integration that school leaders have to overcome.

\section{Research Methodology}

A sequential mixed method approach was used to answer the research questions that guided this study. First, a survey was conducted among principals. Then, a qualitative approach was followed. There are several benefits for using a sequential mixed method approach as it "provides such a wealth of data that researchers discover uses of the ensuing findings that they had not anticipated" (Bryman, 2006, p. 110). Moreover, the mixed method approach was chosen in order to safeguard the purpose of triangulation (seeking convergence of results or corroboration between quantitative and qualitative data), complementarity (identifying different facets of a problem, clarification of the results from the one method with the results from the other), and expansion (adding breadth and scope to the problem) (Greene, Caracelli \& Graham, 1989). 


\section{Quantitative Research}

The target population for the quantitative research was all principals $(\mathrm{N}=336)$ who were employed in public primary schools of Cyprus during the academic year 2007-2008. Using the formula of Krecjie and Morgan (1970) it was estimated that a sample of 180 principals would be representative for the purpose of this study. Questionnaires were sent to 250 principals (in order to account for non-response) using a stratified random sampling approach. The strata of this study were the urban and rural school principals in all educational districts. It has to be clarified that making comparisons among principals of these types of schools was not a primary goal of the study. The reason for using the stratified random sampling and not just a simple random sampling was to obtain a more representative sample from the population of the principals and, therefore, achieve more precise results. The ratio of the target population to the sample population of the principals was about 1.4 which is considered to be a very high ratio.

Data were collected through questionnaires, which were mailed to the principals. One hundred and thirty one completed questionnaires were received (response rate 52.4\%).

In order to assess the principals' attitudes, competence, and use of ICT, a special survey instrument was developed based on the questionnaire "Teachers' Attitudes Toward Computer" (TAC) designed by Christensen and Knezek (1998). The instrument consisted of 55 statements through which principals were required to select their level of agreement for each statement to indicate how they feel towards ICT on a 5-point Likert scale ranging from 1 to 5 where 1 means strongly disagree and 5 strongly agree. The statements were divided in five parallel subscales: enthusiasm-enjoyment, anxiety, avoidance, negative impact on society, and productivity.

The content validity of the instrument was tested in two ways. Firstly, a pilot study was conducted among eight people (five principals, two principals who retired the previous year, and a deputy head who was promoted to the position of principal) in order to (a) check the clarity of the directives, the questions, the statements, as well as the sufficiency of the possible answers, (b) evaluate the appropriateness of the scales, (c) check completion time of the questionnaire, and (d) discard all unnecessary, difficult, or ambiguous questions (Peat, Mellis, Williams, \& Xuan, 2002). Secondly, two teachers - both with doctoral degrees - examined the instrument and made suggestions about the comprehensiveness and the clarity of the instrument.

Internal consistency reliability of the five scales was assessed using Cronbach's alpha. Results indicate that the coefficients were relatively high ranging from .716 (Negative impact on society) to .800 (Avoidance). According to Garson (2008) an instrument is acceptable for research purposes when its reliability using Cronbach's alpha is more than .70 .

Descriptive statistics (means, standard deviations, frequencies, percentages) were used to analyze all data and inferential statistics (t-test, one way ANOVA, and Chi-Square tests) were used to examine potential differences in attitudes towards ICT across principals' background characteristics.

\section{Qualitative Research}

Criterion or purposeful sampling (Marshal, 1996) was used in order to select "the most productive sample to answer the research questions" (p. 523) for the qualitative part of our research. With the assistance of two district ICT advisor teachers (who often visited most of the primary schools), eight principals were selected based on the criteria presented in Table 2: gender, age, type of school, size of school, academic qualifications, and ICT competence. An issue that emerged during the selection of the sample was how would ICT competent principals be identified and chosen. The two district ICT advisor teachers provided the researchers with two lists: (a) a list with the six most progressive schools in ICT integration (three rural and three urban 
schools) placed in ranking from the most progressive to the least progressive school, according to their opinion, and (b) a list with six schools (three rural and three urban) that were left behind in ICT integration, placed again in ranking beginning from the school with the most unsuccessful ICT integration. The researchers contacted eight of the principals that were top on the lists provided and all agreed to participate in the study.

Table 2: Background Characteristics of the principals that were interviewed

\begin{tabular}{|c|c|c|c|c|c|c|}
\hline Name & Gender & $\begin{array}{c}\text { Years of } \\
\text { experience }\end{array}$ & $\begin{array}{l}\text { Level of } \\
\text { studies }\end{array}$ & $\begin{array}{l}\text { Type of } \\
\text { the } \\
\text { school }\end{array}$ & $\begin{array}{c}\text { Size of the school } \\
\text { (number of pupils } \\
\text { - teachers) }\end{array}$ & $\begin{array}{c}\text { ICT } \\
\text { competence }\end{array}$ \\
\hline Head 1 & Female & 36 & $\begin{array}{c}\text { Pedagogical } \\
\text { Academy }\end{array}$ & Rural & Small $(135-11)$ & $\sqrt{ }$ \\
\hline Head 2 & Female & 37 & $\begin{array}{c}\text { Pedagogical } \\
\text { Academy }\end{array}$ & Rural & Small (135 - 13) & \\
\hline Head 3 & Female & 22 & $\begin{array}{c}\text { Doctoral } \\
\text { Degree }\end{array}$ & Urban & Large $(253-25)$ & $\sqrt{ }$ \\
\hline Head 4 & Female & 34 & $\begin{array}{c}\text { Pedagogical } \\
\text { Academy }\end{array}$ & Urban & Large $(285-23)$ & \\
\hline Head 5 & Female & 36 & $\begin{array}{c}\text { Pedagogical } \\
\text { Academy }\end{array}$ & Urban & Small $(159-15)$ & \\
\hline Head 6 & Male & 35 & $\begin{array}{c}\text { Four Master } \\
\text { Degrees }\end{array}$ & Urban & Large $(308-28)$ & $\sqrt{ }$ \\
\hline Head 7 & Male & 38 & $\begin{array}{l}\text { Pedagogical } \\
\text { Academy }\end{array}$ & Rural & Small $(90-10)$ & \\
\hline Head 8 & Male & 20 & $\begin{array}{l}\text { Doctoral } \\
\text { Degree }\end{array}$ & Rural & Large $(225-22)$ & $\sqrt{ }$ \\
\hline
\end{tabular}

Data were collected through semi-structured interviews from the selected school principals. The method of qualitative content analysis (Mayring, 2000) was used for the analysis of the qualitative data. Qualitative data was used for the triangulation of the quantitative results and for the identification of the factors that would facilitate or inhibit ICT integration in primary schools.

\section{Research Findings}

\section{Quantitative Data Analysis}

\section{Demographics}

Table 3 presents the demographics of principals who participated in the quantitative research. Of those principals who took part in the quantitative research, $64.9 \%$ were females and about eight out of ten had access to a computer and the internet at home. Regarding their in-service training on ICT, the majority of them received training for using ICT for personal purposes $(78.6 \%)$ and for using ICT in the teaching and learning process (63.4\%). A very interesting finding is that a higher percentage of them $(82.4 \%)$ had never attended in-service training on ICT for administrative and managerial purposes. Finally, it can be argued that the principals cannot be considered as computer savvy, since only an average of three out of ten principals have been learning or working with computers for more than 10 years. Nevertheless, it should be noted that more years of 
experience with ICT does not necessarily mean that a particular principal has a higher level of expertise in ICT. Regarding the schools' background information, $65.6 \%$ had computer in the principal's office; $84.7 \%$ had a computer in the staff room; and $60.3 \%$ had a computer lab.

Table 3: Frequency distribution of principals' and their schools' demographics

\begin{tabular}{|c|c|c|}
\hline Variable & $\mathbf{N}(\mathbf{1 3 1})$ & $\%$ \\
\hline \multicolumn{3}{|l|}{ Gender } \\
\hline Males & 46 & 35.1 \\
\hline Females & 85 & 64.9 \\
\hline \multicolumn{3}{|l|}{ Years of Service } \\
\hline $18-25$ years & 19 & 14.6 \\
\hline $26-30$ years & 5 & 3.8 \\
\hline $31-35$ years & 62 & 47.8 \\
\hline $36+$ & 44 & 33.8 \\
\hline \multicolumn{3}{|c|}{ Highest Academic qualification } \\
\hline Pedagogical Academy & 93 & 71.0 \\
\hline Bachelor & 14 & 10.7 \\
\hline Master's & 19 & 14.5 \\
\hline $\mathrm{PhD}$ & 5 & 3.8 \\
\hline \multicolumn{3}{|c|}{ Access to a computer at home } \\
\hline Yes & 111 & 84.7 \\
\hline No & 20 & 15.3 \\
\hline \multicolumn{3}{|c|}{ Access to the Internet at home } \\
\hline Yes & 104 & 79.4 \\
\hline No & 27 & 20.6 \\
\hline \multicolumn{3}{|c|}{ In-service education and training (INSET) for using ICT for personal purposes } \\
\hline Yes & 103 & 78.6 \\
\hline No & 28 & 21.4 \\
\hline \multicolumn{3}{|c|}{ INSET for using ICT in teaching and learning } \\
\hline Yes & 83 & 63.4 \\
\hline No & 48 & 36.6 \\
\hline \multicolumn{3}{|c|}{ INSET for using ICT for administration and management } \\
\hline Yes & 23 & 17.6 \\
\hline No & 108 & 82.4 \\
\hline \multicolumn{3}{|c|}{ Existence of a computer in the principal's office } \\
\hline Yes & 86 & 65.6 \\
\hline No & 45 & 34.4 \\
\hline \multicolumn{3}{|c|}{ Existence of a computer in the staff room } \\
\hline Yes & 111 & 84.7 \\
\hline No & 20 & 15.3 \\
\hline \multicolumn{3}{|c|}{ Existence of a computer lab at school } \\
\hline Yes & 79 & 60.3 \\
\hline No & 52 & 39.7 \\
\hline \multicolumn{3}{|c|}{ Computer experience (Years learning about or working with computers) } \\
\hline $1-5$ years & 31 & 27.0 \\
\hline $6-10$ years & 46 & 42.7 \\
\hline $11-15$ years & 19 & 16.5 \\
\hline $16-20$ years & 16 & 13.9 \\
\hline 21 and more years & 1 & 0.9 \\
\hline
\end{tabular}

The results of the survey show that those who hold the position of the principal in primary schools of Cyprus are of advanced age, since the centralized CES is in favour of the seniority rank. Having on average almost 33 years of teaching experience $(\overline{\mathrm{x}}=32.94, \mathrm{SD}=4.87)$, this actually means that principals are very close to their retirement. Interestingly, $81.5 \%$ of the partici- 
pants had more than 31 years of service. It is important to note that teachers in Cyprus have the right to retire after they complete 400 months (or 33 years and 4 months) of service or when they are 60 years old (this is compulsory). Taking into consideration that the mean for years working as a principal is $4.30(\mathrm{SD}=2.46)$, it can be concluded that teachers normally get promoted to the principal's position after they have completed approximately 28 years of service and have five to ten years left to work as principals.

\section{Principals' attitudes towards ICT}

In Table 4 the 55 statements are presented based on their ranking in descending order. It is clear from the results that the primary school principals of Cyprus hold very positive attitudes towards ICT. Almost all principals agree that (a) knowing how to use computers is a worthwhile skill and it is not a waste of time, (b) it is very important for them to learn how to use a computer, and (c) computers can be a useful instructional aid in almost all subject areas. On the contrary, they are skeptical about computers' impact on society, since they believe that computers dehumanize society, isolate people, and have the potential to control people's lives. The results of this study are in agreement with the results of Empirica (2006), which assessed the educators' (teachers and principals) attitudes towards ICT integration and found that Cyprus educators held very positive attitudes towards ICT integration. Similar positive attitudes towards computers, and specifically the internet use as a teaching and learning tool, were found in a study carried out by Charalambous and Ioannou (2008) in 2002-2003 amongst Cypriot primary school educators (including principals).

\section{Table 4: Principals' attitudes towards ICT}

\begin{tabular}{|c|c|c|c|c|}
\hline Statements & Subscale & $N$ & Mean & $S D$ \\
\hline Knowing how to use computers is a worthwhile skill. & 3 & 129 & 4.62 & 0.64 \\
\hline Learning about computers is a waste of time. $*$ & 3 & 128 & 4.60 & 0.64 \\
\hline I believe it is very important for me to learn how to use a computer. & 1 & 128 & 4.46 & 0.65 \\
\hline Computers can be a useful instructional aid in almost all subject areas. & 5 & 129 & 4.45 & 0.53 \\
\hline Computers are changing the world too rapidly. & 4 & 128 & 4.43 & 0.71 \\
\hline If I had a computer at my disposal, I would try to get rid of it. * & 3 & 127 & 4.43 & 0.80 \\
\hline Computers could enhance remedial instruction. & 5 & 129 & 4.42 & 0.53 \\
\hline Not many people can use computers. * & 3 & 127 & 4.42 & 0.74 \\
\hline $\begin{array}{l}\text { Learning to operate computers is like learning any new skill-the more you practice, } \\
\text { the better you become. }\end{array}$ & 3 & 129 & 4.41 & 0.59 \\
\hline I can learn many things when I use a computer. & 1 & 127 & 4.39 & 0.57 \\
\hline Computers can improve education. & 5 & 129 & 4.26 & 0.60 \\
\hline Using computers in school management will improve the operation of most schools. & 5 & 127 & 4.22 & 0.84 \\
\hline The challenge of learning about computers is exciting. & 1 & 129 & 4.20 & 0.78 \\
\hline The internet can bring together people with different cultural, religious, and societal background. & 4 & 129 & 4.13 & 0.65 \\
\hline Having a computer at home is very important for me. & 3 & 126 & 4.10 & 1.00 \\
\hline Working with a computer makes me very nervous. * & 2 & 126 & 4.09 & 1.06 \\
\hline Learning about computers is boring to me. * & 1 & 128 & 4.07 & 1.06 \\
\hline I will probably never learn to use a computer. * & 3 & 128 & 4.06 & 1.15 \\
\hline I get a sinking feeling when I think of trying to use a computer. * & 2 & 127 & 4.02 & 1.09 \\
\hline I like learning on a computer. & 1 & 129 & 3.98 & 0.81 \\
\hline Learning about computers can be an exciting experience. & 1 & 128 & 3.98 & 0.78 \\
\hline Computer usually saves me some time and work. & 5 & 128 & 3.97 & 0.84 \\
\hline Using a computer is very frustrating.* & 2 & 126 & 3.97 & 1.15 \\
\hline Computers could increase my productivity. & 5 & 127 & 3.94 & 0.80 \\
\hline Working with a computer makes me feel tense and uncomfortable. * & 2 & 127 & 3.93 & 1.11 \\
\hline Computers can relieve teachers of routine duties.* & 5 & 127 & 3.93 & 0.85 \\
\hline Using a computer prevents me from being creative. * & 4 & 126 & 3.87 & 0.90 \\
\hline I see the computer as something I will rarely use in my daily life. * & 3 & 127 & 3.83 & 1.01 \\
\hline I enjoy learning how computers are used in our daily lives. & 1 & 126 & 3.83 & 0.91 \\
\hline I am afraid that if I begin to use computers I will become dependent upon them. * & 4 & 126 & 3.82 & 0.95 \\
\hline I would work harder if I could use computers more often. & 1 & 127 & 3.81 & 0.84 \\
\hline It is fun to figure out how computers work. & 1 & 127 & 3.80 & 0.81 \\
\hline I think that working with computers would be enjoyable and stimulating. & 1 & 127 & 3.80 & 0.85 \\
\hline Computers make me feel uncomfortable. * & 2 & 128 & 3.79 & 1.20 \\
\hline I believe that I am a better principal with technology. & 1 & 128 & 3.78 & 1.16 \\
\hline
\end{tabular}




\begin{tabular}{|c|c|c|c|c|}
\hline Statements & Subscale & $N$ & Mean & $S D$ \\
\hline I concentrate on a computer when I use one. & 1 & 127 & 3.75 & 0.93 \\
\hline Computers will only put more work on the shoulders of school administrators. $*$ & 5 & 126 & 3.75 & 0.97 \\
\hline Computers are difficult to use. $*$ & 2 & 127 & 3.74 & 1.16 \\
\hline I can't think of any way that computers will enhance my career. * & 3 & 128 & 3.66 & 1.03 \\
\hline Computers are not exciting. $*$ & 1 & 129 & 3.66 & 1.09 \\
\hline I avoid using computers whenever I can. * & 3 & 127 & 3.63 & 1.17 \\
\hline Capable administrators do not need computers to operate schools efficiently. * & 5 & 129 & 3.60 & 1.14 \\
\hline Use of computers in education reduces the personal treatment of pupils. ${ }^{*}$ & 4 & 127 & 3.54 & 1.00 \\
\hline Computers improve my general job satisfaction. & 5 & 128 & 3.52 & 0.91 \\
\hline I think that computers are very easy to use. & 2 & 128 & 3.41 & 1.02 \\
\hline Working with computers makes me feel isolated from other people. * & 4 & 126 & 3.37 & 0.92 \\
\hline Computers do not scare me at all. & 2 & 126 & 3.33 & 1.26 \\
\hline I feel comfortable working with a computer. & 2 & 127 & 3.31 & 1.15 \\
\hline Computers will create more jobs than they eliminate. & 4 & 128 & 3.17 & 0.80 \\
\hline I like reading about computers. & 1 & 127 & 3.14 & 1.04 \\
\hline I have a lot of self confidence when I work with a computer. & 2 & 126 & 3.07 & 1.11 \\
\hline I like to talk to others about computers. & 1 & 127 & 3.05 & 1.08 \\
\hline Computers dehumanize society by treating everyone as a number. * & 4 & 127 & 2.92 & 0.96 \\
\hline Computers isolate people by inhibiting social interactions among users. * & 4 & 128 & 2.81 & 0.96 \\
\hline Computers have the potential to control our lives. * & 4 & 127 & 2.39 & 0.96 \\
\hline
\end{tabular}

Note: Scales: $1=$ Strongly disagree; $2=$ Disagree; $3=$ Undecided; $4=$ Agree; $5=$ Strongly agree

Subscales: 1=Enthusiasm/Enjoyment; 2=Anxiety; $3=$ Avoidance; $4=$ Negative impact on society;

$5=$ Productivity.

*Negative statements whose score was reversed (the meaning should be reversed in the reader's mind)

\section{The impact of the independent variables}

A number of statistically significant differences were found in principals' attitudes towards ICT (Appendix) across the independent variables. More precisely:

1. Gender: This study is in alignment with other research studies (Charalambous \& Ioannou, 2008) that explored the impact of gender on the attitudes towards computers. The study found that Cyprus male principals hold more positive attitudes towards ICT, without this meaning that female principals have negative attitudes. Statistically significant differences were found in three subscales. More precisely, male principals are more enthusiastic about computers $(\mathrm{t}(127)=2.13, p<0.05)$, have less computer anxiety $(\mathrm{t}(126)=2.23$, $p<0.05)$, and believe to a lesser degree that computers have a negative impact on society $(\mathrm{t}(127)=2.25, p<0.05)$.

2. Years of service: Young principals (who, according to this study, are more computer experienced) are more enthusiastic about $\operatorname{ICT}(F(3,127)=4.98, p<0.01)$, feel less anxiety when using ICT $(F(3,126)=9.63, p<0.001)$, and avoid using computers to a lesser degree $(F(3,127)=8.59, p<0.01)$ than older principals. This result is consistent with findings from previous studies (Busch, 1995; Rosen \& Weil, 1995a, 1995b; Schumacher \& Morahan-Martin, 2001) that concluded that as computer experience increases, computer anxiety drops. On the other hand, the findings of this study contradict the findings of several other studies (Felton, 2006; Pelgrum, 1993) that concluded that age does not play a significant role in determining educators' attitudes towards computers.

3. Academic Qualifications: Principals with postgraduate studies are more enthusiastic about computers $(\mathrm{t}(127)=3.34, p<0.001)$, have less computer anxiety $(\mathrm{t}(43.75)=5.94$, $p<0.001)$, avoid using computers to a lesser degree $(\mathrm{t}(127)=3.88, p<0.001)$, and believe to a lesser degree that computers have a negative impact on society $(\mathrm{t}(127)=2.32$, $p<0.05)$.

4. Access to a computer at home: Principals who have access to a computer at home seem to have more positive attitudes than those who do not have access. In particular, statistically 
significant differences were found in computer enjoyment/enthusiasm $(\mathrm{t}(127)=3.11$, $p<0.01)$, computer anxiety $(\mathrm{t}(126)=3.94, p<0.001)$, and computer avoidance $(\mathrm{t}(127)=$ $6.43, p<0.001)$.

5. Access to the internet at home: Principals with access to the internet at home hold more positive attitudes towards ICT than those who do not have such access. Statistically significant differences were found concerning the principals' access to the internet at home and their enthusiasm and enjoyment when working with computers $(\mathrm{t}(127)=3.15$, $p<0.01)$, their computer anxiety $(\mathrm{t}(126)=3.88, p<0.001)$, their avoidance of using computers $(\mathrm{t}(127)=6.88, p<0.001)$, and their perceptions about the negative impact of computers on society $(\mathrm{t}(127)=3.01, p<0.01)$.

6. In-service training on ICT for teaching and learning purposes: It has been identified that principals who participated in training sessions for teaching and learning purposes have more enthusiasm when working with ICT $(\mathrm{t}(127)=2.40, p<0.05)$, have less computer anxiety $(\mathrm{t}(126)=3.45, p<0.001)$, and avoid using computers to a lesser degree $(\mathrm{t}(127)=$ $3.26, p<0.001)$ than the principals who did not participate in any in-service training sessions for using ICT for teaching and learning purposes. Their participation in these training sessions appeared to raise their level of confidence in using a computer, increase their computer use, and reduce their computer anxiety.

7. Existence of a computer in the principal's office: Principals who have a computer in their school office show more enthusiasm about computers $(\mathrm{t}(127)=4.09, p<0.001)$, have less computer anxiety $(\mathrm{t}(126)=3.17, p<0.01)$, and avoid using computers to a lesser degree $(\mathrm{t}$ $(127)=5.12, p<0.001)$. This is an important finding that policy makers of MOEC should take into consideration if they want to increase the school leaders' positive attitudes towards ICT in order to lead the efforts of ICT integration in their school.

8. Computer Experience: Computer experienced principals feel more enthusiasm and enjoyment when they work with a computer $(F(3,113)=11.87, p<0.001)$, have considerable less computer anxiety $(F(3,112)=14.99, p<0.001)$, avoid using computers to a lesser degree $(F(3,113)=17.79, p<0.001)$, are more optimistic about the impact of computers on society $(F(3,113)=7.61, p<0.001)$, and believe more that computer can raise their productivity $(F(3,113)=5.11, p<0.001)$ compared to principals who have little computer experience. The results of the survey are similar with the results that were found by Schumacher and Morahan-Martin (2001), who concluded that there is an inverse relationship between computer experience and computer anxiety.

\section{Qualitative Data Analysis}

\section{Principals' perceptions about the factors that facilitate or inhibit ICT integration in primary schools of Cyprus}

During the qualitative research, eight principals (Table 2) were asked to express their views about the factors that facilitate or inhibit ICT integration in their schools. Their views covered a wide range of facilitators and inhibitors of ICT integration. The factors that were identified can be divided in two main categories: external and internal factors (Table 5). The existence of these factors can be considered as facilitators whereas their absence can be considered as inhibitors of ICT integration in primary schools of Cyprus.

Principals experienced in using computers referred to the importance of the existence of inspiring and competent leadership during the ICT integration process. According to their views, school leaders should believe in the potentials of ICT and have a clear vision about how ICT could be integrated in their school. As one principal stressed, "the fact that I strongly believe that com- 
puters can make the difference, encouraged me to promote their use in my school." This vision should be stated clearly and should guide the efforts of the school staff. The school leaders must believe, more than anyone else, in the vision and must concentrate their efforts in achieving this. Comprehensive goals should further be set about how this vision could become a reality. Thus, the development of a "technology plan" should be one of their main priorities. It is worth mentioning that three out of the four ICT competent principals (Table 2) who were interviewed stated that their school developed a technology plan with specific goals on ICT integration whereas none of the computer inexperienced principals has developed such a plan. Moreover, the ICT integration efforts should not be sporadic. In fact the goal of ICT integration should be high in the school agenda and the planning for its success should be continuous. One interviewee mentioned that "the integration of technology is a goal that was set by our school staff six years ago and all these years we have made enormous efforts to accomplish it." Additionally, the school leader should be the motivational force who, according to one principal, would "encourage his/her teachers escape from their traditional way of teaching and use technology to improve the quality of their work." However, in order to achieve this the school leaders should make their support visible by making "sure that all the means that are necessary are provided to their teachers and pupils," as another principal added. Resistance to change from some teachers is something that principals should be prepared to deal with. One principal argued that "in order to convince teachers that what I'm telling them (about the potentials of ICT use in the learning process) are not just words, I try to act as their role model."

Table 5: Factors that facilitate or inhibit ICT integration

\begin{tabular}{|l|l|}
\hline \multicolumn{1}{|c|}{ External Factors } & \multicolumn{1}{c|}{ Internal Factors } \\
\hline $\begin{array}{l}\text { In-service training on ICT (provided by } \\
\text { MOEC) }\end{array}$ & $\begin{array}{l}\text { Inspiring and competent leadership } \\
\text { In-service training on ICT (provided by ICT competent } \\
\text { Pupils' background knowledge on ICT } \\
\text { teachers of the school) }\end{array}$ \\
$\begin{array}{l}\text { Technical support-Maintenance } \\
\text { Capision of time to the principals to pre- }\end{array}$ & $\begin{array}{l}\text { Provision of incentives to the school ICT coordinator } \\
\text { Involvement of elementary stakeholders in the integra- } \\
\text { Number of computers per class } \\
\text { Support of the innovation by MOEC }\end{array}$ \\
& $\begin{array}{l}\text { Collaboration with the district ICT advisory teacher } \\
\text { Teachers' competence and knowledge on ICT }\end{array}$ \\
& Acceptance of the innovation by the teachers \\
\hline
\end{tabular}

Another key responsibility of the school leader that could enhance ICT integration in schools, according to another principal, is to build "a culture of innovation and collaboration among the teachers ... which promotes the large use of computers." Finally, building a culture of collaboration and knowledge-sharing among teachers can enhance ICT integration. "... I believe that demonstration lessons from gifted teachers have the power to facilitate the use of computers by more teachers," one principal proposed. To support this view another principal claimed that "I encourage my teachers to visit the classes of their colleagues and observe their teaching methods. I also promote peer teaching between the computer coordinator and the less ICT competent teachers in order to help them overcome their fears."

All the participants recognized that the offering of in-service training sessions on ICT for all the teachers is one of the most important factors that could promote ICT integration in schools. "The Ministry of Education can play an important role. It must organize training sessions for all the teachers, especially on the software programs that are sent to the schools by the Ministry," one participant declared. But some other participants realized that the organization of training sessions on ICT is their responsibility too that could take place during the formal staff meetings. 
The detection of a willing and ICT competent teacher to undertake the role of the school ICT coordinator is an important factor that could enhance ICT integration in schools. What the interviewees stressed is that the coordinator should not only be technical savvy, but he/she should be "willing to communicate his knowledge to other teachers who might not be so familiar with computers."

The principals recognized that the role of the ICT coordinator is very demanding, thus some kind of incentives should be given to those teachers who accept to undertake this responsibility. Giving some extra non-contact time to the coordinator by reducing his/her teaching hours is the only incentive that has been identified by the principals.

Involving the primary stakeholders of the school (teachers, parents, Parents Association, and the School Board) in the integration process has been identified as another facilitator of ICT integration in schools. "Providing parents information about the necessity of this innovation can definitely facilitate the desired ICT integration" one principal stated. Another principal argued that "if parents stop facing computers with skepticism and recognize their importance, then their children will have positive attitudes towards computers too." Finally, all the principals referred to the financial support that schools should have from the Parents Association and the School Board.

Seven out of eight of the interviewees mentioned that the collaboration of their school with the district ICT advisory teacher is one factor that can strengthen their ICT integration efforts. Nevertheless, the principals mentioned that this collaboration could be tighter if there were more district ICT advisory teachers appointed by MOEC because, as one principal argued, "those that are now appointed cannot serve the needs of so many schools."

Innovation is not possible if the teachers are not able or willing to support it (Fullan, 2001). Three interviewees acknowledged that teachers' knowledge and skills on computers is a very important factor that can enhance ICT integration. As one interviewee mentioned, "teachers must have adequate computer skills and use those skills with patience to help all children acquire the basic computer skills and build - step by step - their knowledge on computers."

Two principals identified pupils' background knowledge on ICT as an important facilitator for the ICT integration efforts of the school. As the one principal claims, "if the pupils have sufficient knowledge on computers, this will be very helpful for the teacher."

The achievement of ICT integration very much depends on the technical assistance that schools have during the integration process. All the interviewees expressed their concerns about the inefficient support they get on the technical problems that arise frequently. A very disappointed principal stressed that MOEC should "give a solution to the big problem that concerns the maintenance of the computers." If these problems are continuous and insolvable the ICT integration efforts will surely be threatened.

The existence of only one computer per class was identified by three interviewees as one of the biggest barrier of ICT integration because, as one principal reported, "it is almost impossible for pupils to have access to it and use it."

The integration of ICT is an innovation that alters the traditional way that principals undertake their duties. Principals, especially those who do not have the knowledge on computers, need adequate time to fulfil their administrative duties electronically. This additional time that a principal needs is a big constraint for ICT integration in schools, and it was identified by three of the computer inexperienced principals.

The interviewees recognised that the resistance to change that many teachers express is another big barrier to their ICT integration efforts. As one principal emphatically pointed out, "The biggest enemy of a teacher is the routine. Since he feels secure for what he does, he has no intention 
to experiment and change things." Another one claimed that "people feel threatened that if they apply the innovation, they will be exposed and show their incapability. The solution to this problem will come through familiarization."

The successful integration of ICT in schools depends greatly on the existence of the appropriate infrastructure and, since the educational system of Cyprus is centralized, "the Ministry of Education must provide the necessary infrastructure in order to make the operation of computers possible in each class," one interviewee stated. Moreover, the existence of quality software, aligned with the official curriculum, can enable the use of ICT by teachers. Therefore, as another principal maintained, "The Ministry should try to produce its own software on every subject or translate quality software relevant to our curriculum subjects." Additionally, another principal emphasised "the non-existence of special administrative programs on computers designed to be used by principals in order to facilitate their work." Finally, another barrier that has been identified by the principals is "the demanding official curriculum which puts significant stress on our teachers." Since teachers feel stressed with the national curriculum, it is doubtful they will try to integrate ICT in their classroom practice because, as mentioned before, it is a time consuming process. Especially the "teachers who are not very capable with computers, feel that computers delay them" from covering the syllabus of the official curriculum.

\section{Discussion}

According to the findings of the research, primary school principals in Cyprus hold positive attitudes towards ICT. This is consistent with other research studies that were carried out in various countries (Felton, 2006; Gurr, 2000; Knowledge Foundation, 2003; NetDay, 2008), including Cyprus (Charalambous \& Ioannou, 2008; Empirica, 2006). Nevertheless, it should be noted that even though principals appear very enthusiastic about ICT, believe that ICT can improve productivity, and exhibit low levels of computer anxiety and avoidance of ICT, at the same time they are not computer savvy. It can therefore be inferred that, while principals value the importance of ICT in both the teaching and learning process and in the fulfilment of their managerial and administrative purposes, they still need more tailor-made training and incentives in order to transfer their theoretical enthusiasm into practice.

Regarding the gender effect, this study found that both male and female principals hold positive attitudes towards ICT with males having stronger positive attitudes than their female colleagues. Actually, the findings of this study are well aligned with Whitley's (1996) conclusions who maintained that both - males and females - hold positive beliefs about computers but there is a small gender difference on negative beliefs with women being more anxious about the negative impact of computers on society. However, it should be noted that there are some recent research studies which reveal that the gap between men and women is shrinking or does no longer exist (Bhattacharjee, 2008; Imhof, Vollmeyer, \& Beierlein, 2007; Teo, 2008).

Examining the results about the principals' in-service training on computers, we found that the vast majority of the primary school principals in Cyprus have attended some in-service training sessions for personal and teaching and learning purposes. This is one of the strongest explanations why these principals hold positive attitudes towards ICT, because from several research findings it appears that in-service training is a crucial factor that can improve, on the one hand, principals' attitudes towards ICT and, on the other hand, facilitate principals' efforts to integrate ICT in their school (Dawson \& Rakes, 2003; Knowledge Foundation, 2003). The importance of such training sessions has been emphasized by many scholars. Korukonda (2007), who studied factors contributing to computer anxiety, concluded that computer anxiety could be reduced through continuous education and training rather than just computer-based courses early on. According to Dawson and Rakes (2003), in-service training sessions should be continuous and extended, should correspond to the needs of all the principals, and should be differentiated accord- 
ing to the level of knowledge of the principals. Bearing this in mind, more work needs to be done in this area by the official stakeholders of education in Cyprus, i.e., MOEC, Pedagogical Institute. More precisely, tailor-made courses should be provided to principals with emphasis on how to use the programmes that are available at their schools, how to integrate ICT in teaching and learning, and how to use ICT in educational administration and management. In the last area much more needs to be done since very few courses on how ICT can be used in educational administration and management have been provided in Cyprus (Ethymiou, 2009).

A survey conducted among 23 primary school teachers (including principals) in Cyprus through telephone interviews (Karagiorgi \& Charalambous, 2006) revealed that after ICT training, the majority of the teachers either changed their attitudes towards technology and/or acquired basic skills. However, the same research indicated that there was no significant impact of ICT training on using ICT in the learning process. It seems training practices have only had a significant impact on teachers' attitudinal stance where training participants had overcome their fears through using technology and became empowered by its opportunities on a personal level.

Many research studies conclude that there is a positive correlation between computer experience and positive attitudes, competence and comfort with computers (Schumacher \& Morahan-Martin, 2001) and an inverse relationship between computer experience and computer anxiety (Busch, 1995; Rosen \& Weil, 1995a, 1995b). The more computer experienced a person is, the more confident he/she is with computers. Findings from this research support this assumption since principals with more years of experience working with computers have more positive attitudes. It should be noted that there are some studies that disagree with the above findings, indicating that years of computer experience do not play a significant role in reducing computer anxiety or enhancing positive computer attitudes (Felton, 2006; Pelgrum, 1993).

The current study found that the age-years of service of the principal are an indication of his/her attitudes towards ICT: the fewer years of service he has (therefore the younger he/she is), the more positive attitudes he/she has. The relationship between age and computer attitudes has been investigated in several studies but the results are contradictory. On the one hand, in 2002 the European Commission (as cited in BECTA, 2004c) indicated that as teachers' age increases, the percentages of teachers using computers and the internet decreases. On the other hand, Pelgrum (1993), who investigated the perceptions of principals and teachers towards computers in several countries, found that age does not play an important role in determining the educators' attitudes towards computers. Interestingly, Dawson and Rakes (2003) found that the age of the principal is a critical factor affecting technology integration in schools, with older principals (ages 41 to 55 years) influencing technology integration more than younger principals. They also found that the number of years that the principal has been in his/her administrative position does not influence ICT integration.

Generally, principals' positive attitudes towards ICT are of great importance when it comes to achieving ICT integration in the teaching and learning procedures. According to Pelgrum (1993), "schools, whose principals have positive expectations regarding the educational impact of computers, tend to emphasize computer integrated learning more than schools with principals who are less positive" (p. 209). In addition, Walsh (2002) stresses that ICT integration could be achieved in schools only if school leaders are totally committed over time towards it. As a final point, principals who believe in ICT tend to support the efforts of their staff to integrate technology in their teaching by helping them understand "the potential of the technologies available and of how they can become integrated into the day-to-day life of the school" (BECTA, 2007, p.20).

According to the qualitative data, factors that influence ICT integration in primary schools of Cyprus can be divided in internal and external factors (Table 5). The findings of this research are consistent with the findings of BECTA (2004b), which referred to the lack of teachers' confi- 
dence and teachers' computer anxiety, the lack of access to resources, the lack of time, the technical problems, the resistance to change and negative attitudes of teachers, and the lack of training as the main barriers towards ICT integration in schools. In addition, the findings are aligned with BECTA (2004c), which identified the following as enablers of successful ICT use by teachers: leadership and decision making, whole school planning and implementation of the change, whole school use and development of resources, knowledge sharing and training of teachers, technical support, and some other local and national strategies.

It appears that all the principals - novice or experienced - are aware to some extent of the facilitators and the inhibitors of ICT integration in schools. The external factors cannot be controlled by the principals and are, more or less, the same for all the schools, e.g., number of computers per class, technical support-maintenance, in-service training organized by MOEC, provision of time to the principals to prepare for ICT integration. Even the support that MOEC offers (allocation of resources, technology infrastructure, etc.) is moderately equal for all the schools.

On the other hand, the internal factors are those whose existence depends on the efforts and the leadership capability of the school principal. Competent school leaders with vision on ICT integration are in position to activate these factors and promote ICT integration in their school. The principals that participated in the qualitative research supported this position. Three out of the four computer experienced principals managed to integrate ICT successfully in their schools, not because they managed to control the external factors but because they had a vision about ICT integration and they concentrated their efforts in achieving this vision through a well structured action plan. The fact that these three principals obtained funds (not from MOEC) and allocated a respectable amount of money ( $€ 3000$ to $€ 5000)$ to ICT integration indicates that a well structured action plan can help secure funding from other organisations than MOEC (even for resource allocation and maintenance of ICT).

\section{Concluding Remarks}

The overall conclusion of this study is that ICT integration in primary schools in Cyprus can be facilitated by principals regardless of their access to technology resources and the technical assistance that is provided by MOEC. What is of more importance is the principals' capability to lead the efforts of ICT integration, inspiring their teachers by being "lead learners" (Day, 2003, p. 171) and by enabling "their teachers to act" (Harris, 2003, p. 18) in a desired way. Thus, the primary focus of MOEC should be the strengthening of the principals' leadership skills, giving them "meaningful opportunities to develop the skills and dispositions necessary for leadership in the current educational milieu" (Flanagan \& Jacobsen, 2003, p. 140). According to R. E. Anderson and Dexter (2005), "technology leadership has greater leverage on desired outcomes than does technology infrastructure and expenditures" (p. 73).

\section{References}

Anderson, J. (2010). ICT transforming education: A regional guide. Bangkok: UNESCO.

Anderson, R. E., \& Dexter, S. L. (2005). School technology leadership: An empirical investigation of prevalence and effect. Educational Administration Quarterly, 41(1), 49-82.

Balanskat, A., Blamire, R., \& Kefala, S. (2006). The ICT impact report: A review of studies of ICT impact on schools in Europe, Brussels: European Schoolnet. Retrieved 5 June, 2008 from http://ec.europa.eu/education/pdf/doc254 en.pdf

BECTA. (2004a). What research says about ICT and reducing teachers' workload. Coventry: BECTA. Retrieved 21 September, 2008 from http://partners.becta.org.uk/uploadir/downloads/page documents/research/wtrs_workloads.pdf 
BECTA. (2004b). A review of the research literature on barriers to the uptake of ICT by teachers. Coventry: BECTA. Retrieved 12 July, 2008 from http://partners.becta.org.uk/uploaddir/downloads/page documents/research/barriers.pdf

BECTA. (2004c). Enabling teachers to make successful use of ICT. Coventry: BECTA. Retrieved 15 July, 2008 from http://partners.becta.org.uk/page documents/research/enablers.pdf

BECTA. (2007). The impact of ICT in schools - A landscape review. Coventry: BECTA. Retrieved 6 July, 2008 from http://www.pedagogy.ir/images/pdf/impact_ict_schools.pdf

Bhattacharjee, B. (2008). Factors affecting computer use among older adult users: A study in the backdrop of the Florida State University. Doctoral dissertation. Retrieved 23 July, 2008 from http://etd.lib.fsu.edu/theses/available/etd-01032008-153043/unrestricted/Bonnie.pdf

Bryman, A. (2006). Integrating quantitative and qualitative research: How is it done? Qualitative Research, 6(1), 97-113.

Busch, T. (1995). Gender differences in self-efficacy and attitudes toward computers. Journal of Educational Computing Research, 12(2), 147-158.

Charalambous, K., \& Ioannou, I. (2008). The attitudes and opinions of Cypriot primary teachers about the use of the internet for their professional development and as an educational tool. Learning, Media and Technology, 33(1), 45-57.

Charalambous, K., \& Karagiorgi, Y. (2002) Information and communications technology in-service training for teachers: Cyprus in perspective. Technology, Pedagogy and Education, 11(2), 197-215.

Christensen, R., \& Knezek, G. (1998, March). Parallel forms for measuring teachers' attitudes toward computers. Presented at Society of Information Technology \& Teacher Education (SITE)'s 9th International Conference, Washington, DC. Retrieved 29 March, 2008 from http://www.tcet.unt.edu/pubs/studies/sitetac/sld001.htm .

Day, C. (2003). Successful leadership in the twenty-first century. In A. Harris, C. Day, D. Hopkins, M. Hadfield, A. Hargreaves, \& C. Chapman (Eds), Effective leadership for school improvement (pp. 157179). New York: Routledge Falmer.

Dawson, C., \& Rakes, G. C. (2003). The influence of principals' technology training on the integration of technology into schools. Journal of Research on Technology in Education, 36, $29-49$.

Dion, P. D. (2005). The Lisbon process: A European odyssey. European Journal of Education, 40(3), 295313.

Doratis, L. (2007). Information and communication technology projects of the Ministry of Education and Culture of Cyprus. Retrieved 6 May, 2008 from http://www.moec.gov.cy/presentations/ppt/Presentation_for_ICT.ppt

Empirica. (2006). Benchmarking access and use of ICT in European schools: Final report from head teacher and classroom teacher surveys in 27 European countries. Retrieved 15 August, 2008 from http://ec.europa.eu/information_society/eeurope/i2010/docs/studies/final_report 3.pdf

Eteokleous, N. (2008). Evaluating computer technology integration in a centralized school system. Computers \& Education, 51(2), 669-686.

Ethymiou, I. (2009). Introduction of school management system in Cypriot schools, Using ICT in educational administration and management, CIIM, Nicosia, 14 March 2009.

Eurydice. (2011). Key data on learning and innovation through ICT at school in Europe 2011, European Commission. Retrieved 15 September, 2011 from http://eacea.ec.europa.eu/education/eurydice/documents/key data series/129EN.pdf

Felton, F. S. (2006). The use of computers by primary school principals. Doctoral dissertation, Virginia Polytechnic Institute and State University, Blacksburg, Virginia. Retrieved 26 July, 2008 from http://scholar.lib.vt.edu/theses/available/etd-04242006-144854/unrestricted/FFelton04202006.pdf 
Fishbein, M., \& Ajzen, I. (1975). Belief, attitude, intention, and behavior: An introduction to theory and research. Reading, MA: Addison-Wesley. Retrieved 9 July, 2008 from http://people.umass.edu/aizen/f\&a1975.html

Flanagan, L., \& Jacobsen, M. (2003). Technology leadership for the twenty-first century principal. Journal of Educational Administration, 41(2), 124-142.

Fullan, M. (2001). The new meaning of educational change. NY: Teachers College Press

Garson, G. D. (2008). Reliability analysis. Retrieved 26 September, 2008 from http://www2.chass.ncsu.edu/garson/pa765/reliab.htm

Greene, J. C., Caracelli, V. J., \& Graham, W. F. (1989). Toward a conceptual framework for mixed-method evaluation designs. Educational Evaluation and Policy Analysis, 11(3), 255-274.

Gurr, D. (2000). School principals and information and communication technology. Paper presented at the International Learning Conference 2000, Melbourne, Australia. Retrieved 24 July 2008 from http://staff.edfac.unimelb.edu.au/ davidmg/papers/Gurr_Conf_Paper.pdf

Harris, A. (2003). The changing context of leadership: Research, theory and practice. In A. Harris, C. Day, D. Hopkins, M. Hadfield, A. Hargreaves, \& C. Chapman (Eds), Effective leadership for school improvement (pp. 261-270). New York: Routledge Falmer.

Imhof, M., Vollmeyer, R., \& Beierlein C. (2007). Computer use and the gender gap: The issue of access, use, motivation, and performance. Computers in Human Behavior, 23, 2823-2837.

Jimoyiannis, A., \& Komis, V. (2007). Examining teachers' beliefs about ICT in education: Implications of a teacher preparation programme. Teacher Development, 11(2), 149-173.

Karagiorgi, Y., \& Charalambous, K. (2004). Curricula considerations in ICT integration: Models and practices in Cyprus. Education and Information Technologies, 9(1), 21-35.

Karagiorgi, Y., \& Charalambous, K. (2006). ICT in-service training and school practices: In search for the impact. Journal of Education for Teaching, 32(4), 395-411.

Knowledge Foundation. (2003). ICT in Schools 2003. Sweden: The Knowledge Foundation. Retrieved 7 August, 2008 from http://www.kks.se/upload/publikationsfiler/it_i utbildning/ict in_schools_2003.pdf

Korukonda, A. R. (2007). Differences that do matter: A dialectic analysis of individual characteristics and personality dimensions contributing to computer anxiety. Computers in Human Behavior, 23(4), 19211942.

Korukonda, A. R., \& Finn, S. (2003). An investigation of framing and scaling as confounding variables in information outcomes: The case of technophobia. Information Sciences, 155(1-2), 79-88.

Krecjie, R. V., \& Morgan, D. W. (1970). Determining sample size for research activities. Educational and Psychological Measurement, 30, 607-610.

Marshal, M. N. (1996). Sampling for qualitative research. Family Practice, 13(6), 522-526.

Mayring, P. (2000). Qualitative content analysis. Forum: Qualitative Sozialforschung / Forum: Qualitative Social Research, 1(2), Art. 20. Retrieved 13 April, 2008 from http://www.qualitative-research.net/ index.php/ fqs/article/viewArticle/1120/2487

Ministry of Education and Culture. (2007a). Annual report-2006. Nicosia, Ministry of Education and Culture. Retrieved 23 April, 2008 from http://www.moec.gov.cy/etisia- ekthesi/pdf/Annual_report_2006_en.pdf

Ministry of Education and Culture. (2007b). Strategic planning for education: The whole reform of our educational system. Republic of Cyprus, Ministry of Education and Culture. Retrieved 3 May, 2008 from http://www.moec.gov.cy/stratigikoi_sxediasmoi/pdf/17_1_2008_stratigikos_shediasmos anatheorimenos.pdf 
Ministry of Education and Culture. (2008). Official regulations about the functioning of public primary schools 225/2008. Republic of Cyprus, Ministry of Education and Culture. Retrieved 13 August, 2011 from http://www.moec.gov.cy/dde/pdf/kanonismoi_stoixeiodous_ekpaidevsis2008.pdf

Moldafsky, N. I., \& Kwon, I. K. (1994). Attributes affecting computer-aided decision making: A literature survey. Computers in Human Behavior, 10(3), 299-323.

Mrazek, R., Hollingsworth, M., \& Street, M. (2005). Scaling the digital leadership divide. In C. Crawford, R. Carlsen, I. Gibson, K. McFerrin, J. Price, R. Weber, \& D. A. Willis (Eds.), Society for Information Technology \& Teacher Education International Conference Annual (pp. 1819-1826). Norfolk, VA: AACE.

Murphy, J., \& Shipman, N. (1999). The Interstate School Leaders Consortium: A standards-based approach to strengthening educational leadership. Journal of Personnel Evaluation in Education, 13(3), 205224.

Newhouse, C. P. (2002). Literature review: The Impact of ICT on learning and teaching. Western Australian Department of Education. Retrieved 10 September, 2011 from http://www.det.wa.edu.au/education/cmis/eval/downloads/pd/impactreview.pdf

NetDay. (2008). Speak up 2007 for students, teachers, parents \& school leaders: Selected national findings. Retrieved 11 August, 2008 from http://www.tomorrow.org/docs/National\%20Findings\% 20Speak\%20Up\%202007.pdf

Peat, J., Mellis, C., Williams, K., \& Xuan W. (2002). Health science research: A handbook of quantitative methods. London: Sage.

Pelgrum, W. J. (1993). Attitudes of school principals and teachers towards computers: Does it matter what they think? Studies in Educational Evaluation, 19(2), 199-212.

Rosen, L., \& Weil, M. (1995a). The psychological impact of technology from a global perspective: A Study of technological sophistication and technophobia in university students from twenty-three countries. Computers in Human Behavior, 11(1), 95-133.

Rosen, L., \& Weil, M. (1995b). Computer availability, computer experience and technophobia among public school teachers. Computers in Human Behavior, 11(1), 9-31.

Schumacher, P., \& Morahan-Martin, J. (2001). Gender, internet and computer attitudes and experiences. Computers in Human Behavior, 17(1), 95-110.

Sciadas, G. (2004). International benchmarking for the information society. Busan, Republic of Korea. Retrieved 16 September, 2011 from http://www.itu.int/osg/spuold/ni/digitalbridges/docs/background/BDB-intl-indices.pdf

Scrimshaw, P. (2004). Enabling teachers to make successful use of ICT, BECTA. Retrieved 12 September, 2011 from http://www.kentrustweb.org.uk/UserFiles/KICT/File/ICT/support/enablers.pdf

Teo, T. (2008). Pre-service teachers' attitudes towards computer use: A Singapore survey. Australasian Journal of Educational Technology, 24(4), 413-424.

Todman, J. (2000). Gender differences in computer anxiety among university entrants since 1992. Computers \& Education, 34(1), 27-35.

Walsh, K. (2002). ICT's about learning: School leadership and the effective integration of information and communications technology. Nottingham: National College for School Leadership. Retrieved 13 July, 2008 from http://forms.ncsl.org.uk/mediastore/image2/walsh-ict-full.pdf

Wen, J. R., \& Shih, W. L. (2008). Exploring the information literacy competence standards for elementary and high school teachers. Computers \& Education, 50(3), 787-806.

Whitley, B.E., Jr. (1996). Gender differences in computer-related attitudes: It depends on what you ask. Computers in Human Behavior, 12(2), 275-289. 


\section{Appendix}

Attitudes towards ICT of the principals \& Independent Variables

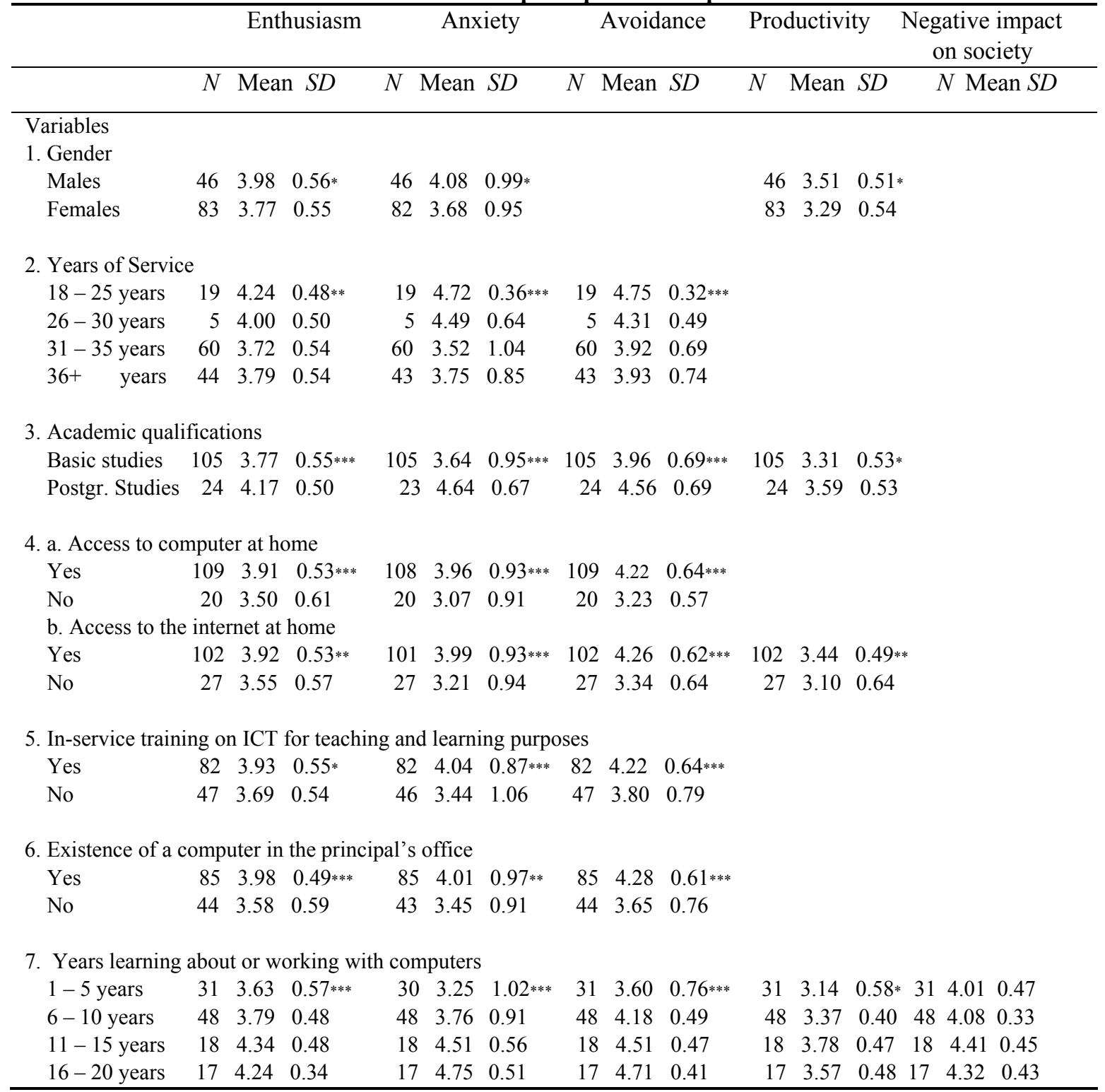

\begin{tabular}{|c|c|c|c|c|c|c|}
\hline Negative Attitudes & \multicolumn{3}{|c|}{ SCALE } & Positive Attitudes \\
\hline $\begin{array}{c}\text { Low enthusiasm/enjoyment } \\
\text { High computer anxiety } \\
\text { High avoidance } \\
\begin{array}{c}\text { Low productivity } \\
\text { High negative impact on society }\end{array}\end{array}$ & 1 & 2 & 3 & 4 & 5 & $\begin{array}{c}\text { High enthusiasm/enjoyment } \\
\text { Low computer anxiety } \\
\text { Low avoidance } \\
\text { High productivity }\end{array}$ \\
$\begin{array}{l}* p<0.05 \\
* * p<0.01\end{array}$ \\
$* * * p<0.001$
\end{tabular}




\section{Biographies}

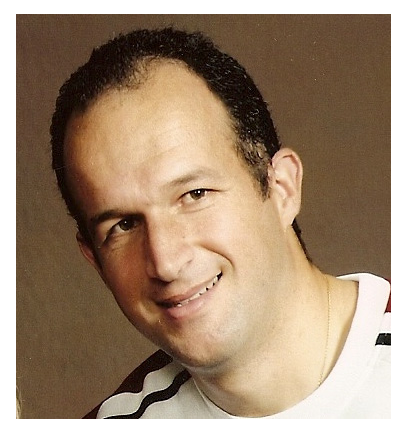

Photos Papaioannou has been working as a primary school teacher in Cyprus for the past eighteen years. He received a Teaching Diploma from the Pedagogical Academy of Cyprus and a BEd from the Aristotle University of Thessaloniki. In 2008 he received his MSc in Educational Leadership and Management from the Cyprus International Institute of Management (CIIM) in Nicosia. In the past two years he participated in scientific conferences and published research papers in the proceedings of these conferences.

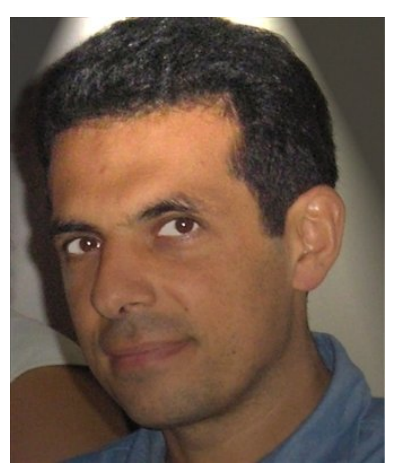

Dr Kyriacos Charalambous received a Teaching Diploma from the Pedagogical Academy of Cyprus and a BEd from the University of Athens, Greece. He complicated his Master in Computer Education, and his $\mathrm{PhD}$ in Information and Communication Technology (ICT) in Education at the Birmingham University in Britain in 2001. The topic of his research was "An Investigation of the Provision of ICT InService Education and Training for Cypriot Primary Teachers". He also got a postgraduate diploma in Research Methods in Education from the same university. At present he works as an Assistant Professor of ICT in Education, in the School of Education at the Frederick University in Cyprus. He has broad professional experience working with educators and other educational personnel in Cyprus on the implementation of ICT in teaching and learning, educational administration and management, teachers' in-service training, elearning and ICT in environmental studies. He has written 12 research papers for refereed journals and published more than 35 research papers in the proceedings of scientific conferences. 